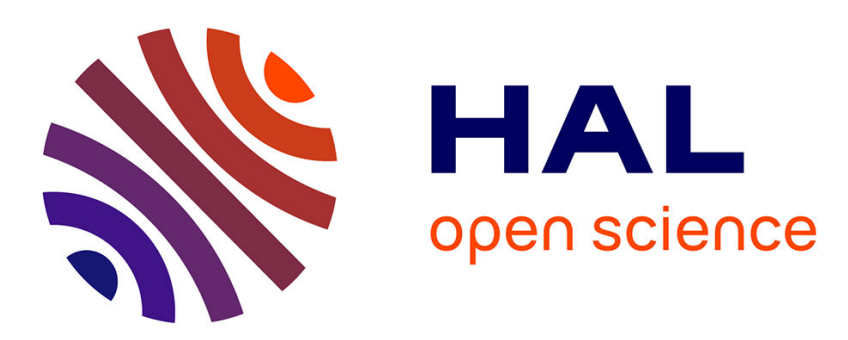

\title{
Dielectric dispersion of irradiated BaTio3 near the phase transition
}

\author{
V.V. Demjanov, S.P. Solov'Ev
}

\section{To cite this version:}

V.V. Demjanov, S.P. Solov'Ev. Dielectric dispersion of irradiated BaTio3 near the phase transition. Revue de Physique Appliquée, 1972, 7 (2), pp.81-82. 10.1051/rphysap:019720070208100 . jpa00243608

\section{HAL Id: jpa-00243608 https://hal.science/jpa-00243608}

Submitted on 1 Jan 1972

HAL is a multi-disciplinary open access archive for the deposit and dissemination of scientific research documents, whether they are published or not. The documents may come from teaching and research institutions in France or abroad, or from public or private research centers.
L'archive ouverte pluridisciplinaire HAL, est destinée au dépôt et à la diffusion de documents scientifiques de niveau recherche, publiés ou non, émanant des établissements d'enseignement et de recherche français ou étrangers, des laboratoires publics ou privés. 


\title{
DIELECTRIC DISPERSION OF IRRADIATED $\mathrm{BaTiO}_{3}$ NEAR THE PHASE TRANSITION
}

\author{
V. V. DEMJANOV and S. P. SOLOV'EV \\ Karpov Institute of Physical Chemistry, Moscow, USSR
}

(Reçu le 16 novembre 1971, révisé le 10 février 1972)

\begin{abstract}
Résumé. - Jusqu'à la fréquence de $1,5 \times 10^{10} \mathrm{~Hz}$ la perméabilité diélectrique et les pertes diélectriques ont été étudiées dans $\mathrm{BaTiO}_{3}$ polycristallin irradié dans la pile jusqu'au flux intégré de neutrons rapides $\varphi \simeq 5 \times 10^{19} \mathrm{~cm}^{-2}$. Lors de $\varphi_{\mathrm{c}} \simeq 5 \times 10^{18} \mathrm{~cm}^{-2}$ on a découvert l'accroissement brusque de la fréquence de dispersion $f_{0}$ et la transformation d'état induite par irradiation qui correspondent au maximum de la dépendence de $\varepsilon$ avec $\varphi$. Les changements qualitatifs observés de $\varepsilon$ et $f_{0}$ sont analogues à ceux des mêmes paramètres au voisinage du point de Curie pour $\mathrm{BaTiO}_{3}$ non irradié. Lors de $\varphi<\varphi_{\mathrm{c}}$ la valeur mesurée du déplacement de la constante de Curie dans la direction des températures inférieures dépend de la fréquence selon la loi $\Delta T_{\mathrm{c}}(f)=\Delta T_{0} \cdot \ln \left(f_{0}^{\prime} / f\right)$ ou $\Delta T_{0}=4-5^{\circ} \mathrm{C}$ et $f_{0}^{\prime} \simeq 10^{11} \mathrm{~Hz}$.
\end{abstract}

\begin{abstract}
Frequency dependence of the dielectric constant $\left(\varepsilon^{\prime}\right)$ and $\operatorname{tg} \delta$ up to $1.5 \times 10^{10} \mathrm{c} / \mathrm{s}$ have been measured for polycrystalline $\mathrm{BaTiO}_{3}$ irradiated with fast neutron integrated fluxes up to $\varphi \simeq 5 \times 10^{19} \mathrm{~cm}^{-2}$. The radiation induced phase transition takes place at $\varphi_{\mathrm{c}} \simeq 5 \times 10^{18} \mathrm{~cm}^{-2}$ corresponding to a maximum in the $\varepsilon$ vs $\varphi$ dependence and a fairly sharp increase in the dispersion frequency $f_{0}$. Qualitatively, changes of $\varepsilon^{\prime}$ and $f_{0}$ are analogous to these near the Curie point for non-irradiated $\mathrm{BaTiO}_{3}$. At $\varphi<\varphi_{\mathrm{c}}$ the Curie point shift to lower temperatures depends upon the frequency according to the law $\Delta T_{\mathrm{c}}(f)=\Delta T_{0} \ln \left(f_{0}^{\prime} / f\right)$, where $\Delta T_{0}=4-5{ }^{\circ} \mathrm{C}$ and $f_{0}^{\prime} \simeq 10^{11} \mathrm{c} / \mathrm{s}$.
\end{abstract}

It is known that irradiation of $\mathrm{BaTiO}_{3}$ by fast neutrons causes the Curie point to shift to lower temperatures including a radiation induced phase transition into the paraelectric state at integrated neutron fluxes $\varphi>10^{18} \mathrm{~cm}^{-2}$ [1]-[4]. One qualitatively observed similar changes in $\mathrm{BaTiO}_{3}$ crystal lattice parameters as a function of both $T$ and $\varphi$.

For a more detailed study of the radiation induced phase transformation in $\mathrm{BaTiO}_{3}$ the dielectric properties $\left(\varepsilon^{\prime}\right.$ and $\left.\operatorname{tg} \delta\right)$ of in-pile irradiated polycrystalline samples of $\mathrm{BaTiO}_{3}$ were measured at radio and microwave frequencies using the method described in [5].

Low signal dielectric constant $\varepsilon^{\prime}$ vs $\varphi$ dependences

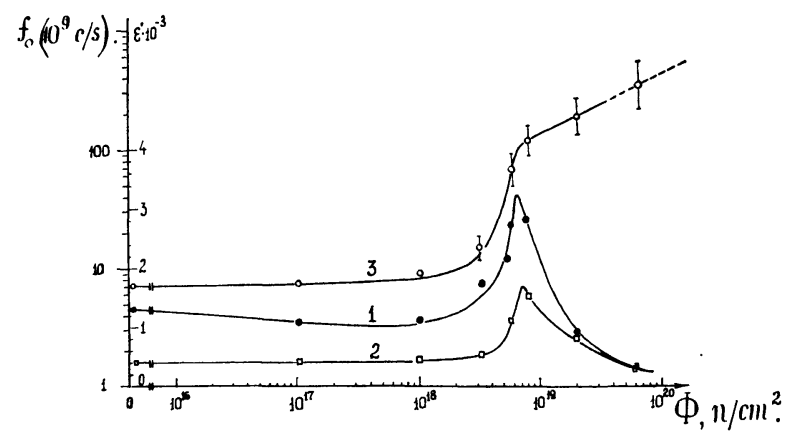

Fig. 1. - Dielectric constant $\varepsilon^{\prime}$ (curves 1,2) and frequency $f_{0}$ of microwave dispersion (curve 3) vs integrated fast neutron flux for polycrystal $\mathrm{BaTiO}_{3}$. Curves 1 and 2 measured at $50^{\circ} \mathrm{C}$ and at the frequencies $3 \times 10^{5}$ and $1.5 \times 10^{10} \mathrm{c} / \mathrm{s}$ respectively. are shown in figure 1 for the range of frequencies $3 \times 10^{5} \mathrm{c} / \mathrm{s}$ and $1.5 \times 10^{10} \mathrm{c} / \mathrm{s}$. It follows from figure 1 that at $\varphi \equiv \varphi_{\mathrm{c}} \simeq(3-6) \times 10^{18} \mathrm{~cm}^{-2}$, corresponding to the radiation induced phase transition [1]-[4], one observes in the $\varepsilon^{\prime}(\varphi)$ dependence an anomalous increase of $\varepsilon^{\prime}$ similar to that in the $\varepsilon^{\prime}(T)$ dependence at $T=T_{\mathrm{c}}$ for non-irradiated $\mathrm{BaTiO}_{3}$. In the $\varphi<\varphi_{\mathrm{c}}$ range $\left(<10^{18} \mathrm{~cm}^{-2}\right)$ one observes an increase in frequency corresponding to the start

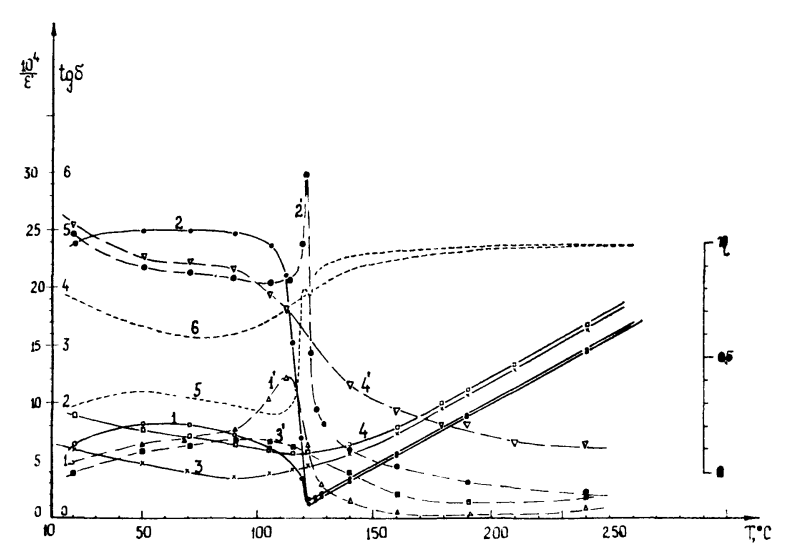

FIG. 2. - Temperature dependences of $\varepsilon^{\prime}$ (curves 1-4) $\operatorname{tg} \delta$

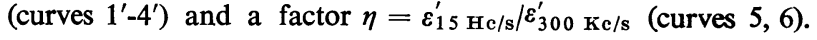
$1,1^{\prime}, 2,2^{\prime}, 5$ - before irradiation $(\varphi=0)$.

$3,3^{\prime}, 4,4^{\prime}, 6$ - after irradiation $\varphi=6 \times 10^{18} \mathrm{~cm}^{-2}$.

Curves $1,1^{\prime}, 3,3^{\prime}$ and $2,3^{\prime}, 4,4^{\prime}$ measured at frequencies $3 \times 10^{5}$ and $1.5 \times 10^{10} \mathrm{c} / \mathrm{s}$ respectively. 
of microwave dispersion, and one also observes an increase in the frequency $f_{0}$ corresponding to the midpoint of the dispersion which is also determined from the maximum of the $\varepsilon^{\prime \prime}(f)$ curve. Herewith the value of the dielectric constant, corresponding to the end of the dispersion, remains practically unchanged. These changes of the $\mathrm{BaTiO}_{3}$ dielectric spectrum (not shown in Fig. 1-3) are in agreement with the assumption of domain fractionation as in the case of electron irradiation [5].

The data shown in figures 2 and 3 also testify to the fact that ferroelectric $\mathrm{BaTiO}_{3}$ displays the properties of the paraelectric phase more and more

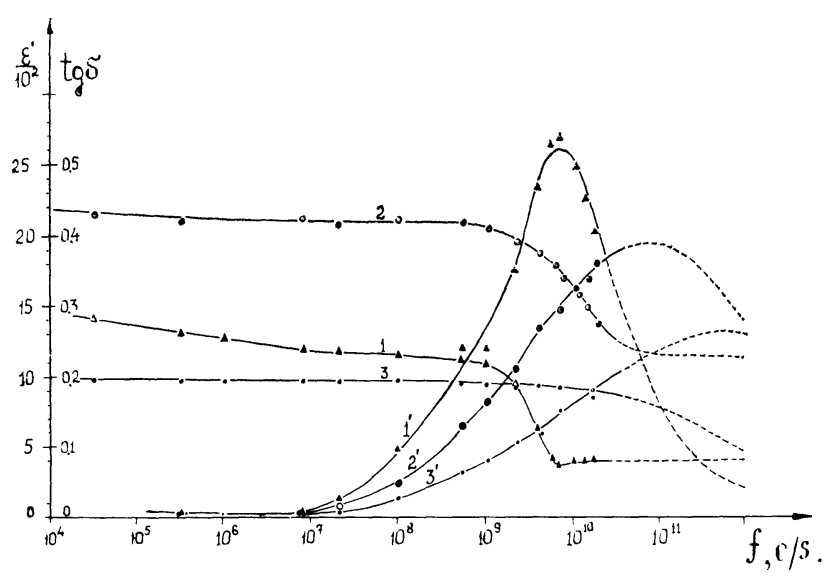

FIG. 3. - Frequency dependences of $\varepsilon^{\prime}$ (curves 1-3) and tg $\sigma$ $\left(1^{\prime}-3^{\prime}\right)$ for neutron irradiated $\mathrm{BaTiO}_{3}$.

$$
\begin{aligned}
& 1,1^{\prime}-\text { before irradiation }(\varphi=0) . \\
& 2,2^{\prime}-\varphi=6 \times 10^{18} \mathrm{~cm}^{-2} . \\
& 3,3^{\prime}-\varphi=2 \times 10^{19} \mathrm{~cm}^{-2} .
\end{aligned}
$$

intensively with increasing $\varphi$. In particular, the frequency $f_{0}$ increases and at $\varphi>\varphi_{\mathrm{c}}$ gets into the frequency range characteristic of infrared dispersion of $\mathrm{BaTiO}_{3}$ (Fig. 1). At $\varphi \simeq \varphi_{\mathrm{c}}$ in parallel with the $f_{0}$ increase, parameters of the Curie-Weiss law irreversibly change; $T_{\mathrm{c}}$ shifts to lower temperatures and the value of $\varepsilon_{0}^{\prime}$ and $\varepsilon_{\infty}^{\prime}$ increase (Fig. 1).

At the same time one observes the broadening of the $\varepsilon^{\prime}(T)$ and $\operatorname{tg} \delta(T)$ curves measured both at low and microwave frequencies (Fig. 2). Herewith within the temperature range $T<T_{\mathrm{c}}, \operatorname{tg} \delta$ decreases and a factor $\eta$, which is called the depth of dispersion (see Fig. 2), increases. Within the range $T>T_{\mathrm{c}}$ the oposite occurs. Upon irradiating simultaneously with the phase transition broadening, some details of the $\varepsilon^{\prime}(T), \operatorname{tg} \delta(T)$ and $\eta(T)$ curves observed for nonirradiated $\mathrm{BaTiO}_{3}$ [6], [7], vanish.

It is noteworthy that the $f_{0}(\varphi)$ behaviour near $\varphi_{\mathrm{c}}$ appears to be qualitatively similar to the $f_{0}(T)$ dependence near $T_{\mathrm{c}}$ for non-irradiated $\mathrm{BaTiO}_{3}$ [6], [7] and must be related to the radical changes of domain structure at the radiation induced phase transition, namely to the transformation of domain structure into a dynamically stable system of nuclei of spontaneous polarization (polarization fluctuations) in the paraelectric phase [8]. The accumulation of high barrier radiation defects as a reason for the $T_{\mathrm{c}}$ shift [2], [3] must cause simultaneously, the decrease of the correlation radius of atomic displacements in the polarization nuclei and hence result in the observed increase of the dispersion frequency $f_{0}$ (Fig. 1).

It is of interest that the phase transition temperature shift $\Delta T_{\mathrm{c}}$, obtained from the data shown in figure 2 at $\varphi \approx \varphi_{\mathrm{c}}$, depends upon frequency according to the law $\Delta T_{\mathrm{c}}(f)=\Delta T_{0} \ln \left(f_{0}^{\prime} / f\right)$ where $\Delta T_{0}=4-5^{\circ} \mathrm{C}$ and $f_{0}^{\prime} \simeq 10^{11} \mathrm{c} / \mathrm{s}$. The $\Delta T_{\mathrm{c}}(f)$ behaviour for neutron irradiated $\mathrm{BaTiO}_{3}$ is evidence of relaxation processes whose threshold energy is about $3 \mathrm{eV}$ per defect at $\varphi=8 \times 10^{18} \mathrm{~cm}^{-2}$.

\section{References}

[1] HAuser (O.) and Schenk (M.), Phys. Stat. Sol., 1966, $18,547$.

[2] Kuzmin (I. I.), Solov'ev (S. P.), ZaKurkin (V. V.), Izv. Akad. Sci. USSR, Ser. Fiz., 1969, 33, 354.

[3] Solov'ev (S. P.), KuZmin (I. I.) and ZAKURKIN (V. V.). Ferroelectrics, 1970, 1, 19.

[4] Solov'ev (S. P.), KuZmin (I. I.), Izv. Akad. Sci. USSR, Ser. Fiz. 1970, 34, 2604.
[5] Demuanov (V. V.), Solov'ev (S. P.), Izv. Akad. Sci. USSR, Ser. Fiz., 1967, 31, 1874.

[6] Demuanov (V. V.), Solov'ev (S. P.), Izv. Akad. Sci. USSR, Ser. Fiz., 1970, 34, 2581.

[7] Demuanov (V. V.), Fiz. Tverd. Tela, 1970, 12, 2407.

[8] Demuanov (V. C.), Solov'ev (S. P.), Izv. Akad. Sci. USSR, Ser. Fiz., 1969, 33, 236. J. Phys. Soc. Japan, 1970, 28 (Suppl.), 181. 